\title{
Social Explanations of Lottery Play: New Evidence Based on National Survey Data
}

\author{
Mark Lutter ${ }^{1} \cdot$ Daria Tisch $^{2} \cdot$ Jens Beckert $^{3}$
}

\section{MPIfG Journal Article}

Mark Lutter, Daria Tisch, Jens Beckert: Social Explanations of Lottery Play: New Evidence Based on National Survey Data 34(4), 1185-1203 (2018). Springer

The original publication is available at the publisher's web site: https://doi.org/10.1007/s10899-018-9748-0

The MPIfG Journal Articles series features articles by MPIfG researchers and visiting scholars published in peer-reviewed journals. Max Planck Institute for the Study of Societies (MPIfG) Cologne | www.mpifg.de

Published online: 21 February 2018

(C) Springer Science+Business Media, LLC, part of Springer Nature 2018

\begin{abstract}
This study examines the social contexts of gambling and analyzes social motivations for playing the lottery. We test three sociological approaches simultaneously: network effects, consumption theory, and strain theory. The data used (SOEP-IS, $\mathrm{N}=5868$ individuals) has several advantages beyond being a large-scale representative sample of the German population. With information on households, we can analyze social network effects while avoiding the problems of egocentric network data. Another benefit of the SOEP-IS is the panel structure. We use the panel structure to improve measurements of strain theory by using the decline in income over time as a measure for it. Our results suggest that the three theories explain different aspects of lottery play. Networks seem to have an influence on lottery play. Having another person in the household playing the lottery is positively associated with both the probability of playing (regularly) and expenditures on lottery tickets. Daydreams and the belief in good luck are positively associated with lottery play as well. Strain theory is confirmed insofar as we find that a decline in income is significantly related to expenditures but not to the probability of playing the lottery. Overall, this study suggests that people play the lottery depending on their social surroundings, their desire to participate in a world normally out of their reach, and the tensions they feel from the distance between their aspirations and their actual social position.
\end{abstract}

Keywords Lottery play $\cdot$ Sociology $\cdot$ Social networks $\cdot$ Strain theory $\cdot$ Imaginative values

Mark Lutter

lutter@uni-wuppertal.de

1 University of Wuppertal, Gaußstr. 20, 42119 Wuppertal, Germany

2 University of Cologne, Cologne, Germany

3 Max Planck Institute for the Study of Societies, Cologne, Germany 


\section{Introduction}

More than 200 years ago, Adam Smith pointed to lottery players' errors in judgment and stated that the "vain hope of gaining some of the great prizes is the sole cause of this demand [for lottery tickets]" (Smith 1904 [1776]:I.10.30). Ever since, it has primarily been economists and psychologists who have attempted to explain the motivation for lottery gambling. They have done so by recourse to individualistic factors, especially cognitive biases (for a review, see Ariyabuddhiphongs 2011). It has been found that irrational beliefs about probability, random events, and the chance of winning, belief in good luck, and personality traits (e.g., impulsivity) are associated with lottery play (Ariyabuddhiphongs and Chanchalermporn 2007; Chiu and Storm 2010; Ladouceur et al. 1995; Pravichai and Ariyabuddhiphongs 2014; Rogers 1998; Rogers and Webley 2001). In contrast, empirical sociological investigations of the causes that people participate in lotteries are scarce. Only a few sociological studies exist (for a recent review, see Beyerlein and Sallaz 2017; Sarti and Triventi 2017). These studies focus on several aspects of lottery play. Garvía (2007) and Guillén et al. (2012) address the question of why people play the lottery in syndicates. They emphasize that individuals play in syndicates primarily for social reasons, for example to cement membership and status position in social networks. Rosecrance (1986) and Adams $(1996,2001)$ examine binding social arrangements as causes for the persistence of lottery play. Beckert and Lutter (2013) examine why it is especially the poor who play the lottery. They find that peer play, educational attainment and self-perceived social deprivation are correlated with lottery expenditures. Recently, economists have also turned to more social explanations-e.g. positive emotions before the draw, the imaginative qualities of lottery play, social status, and social networks - and tested them (Burger et al. 2016; Forrest et al. 2002; Friehe and Mechtel 2015; Humphreys and Perez 2013; Kocher et al. 2014). With the exception of Beckert and Lutter (2013), studies analyze only one explanation at a time or pool different sociological explanations.

We integrate motivational and involvement models to explain both why people play the lottery at all and why some people have higher expenditures on lottery tickets than others do (Binde 2013). Instead of examining a single explanation, we explore three sociological explanations simultaneously. The first explanation is social network-related effects. People can play the lottery due to social contagion or simply because they seek shared experiences with friends. Second, lottery play has imaginative social qualities. Buying lottery tickets enables a hope of winning and thus indulging in daydreams of a better future. And third, according to strain theory, playing the lottery relieves tensions felt by individuals who experience status inconsistencies. In the following, we describe the three sociological explanations of lottery play in detail.

\section{Social Network Effects}

To understand who plays the lottery, it is promising to look at both the causal effects of social networks and pure selection effects. Regarding the latter, one needs to consider the homophily principle from social network theory, according to which people's close surroundings within networks are homogeneous in terms of many socio-demographic characteristics, attitudes, and behaviors (McPherson et al. 2001). Individuals choose their close ties based on common attitudes, including towards gambling. The homophily principle also applies to households and families. Although strong affective bonds among families also allow for heterophily regarding some behavioral characteristics or attitudes, "family ties are homophilous on most characteristics" (McPherson et al. 2001:431). It is therefore 
reasonable to expect that household members are similar in their gambling behavior, and that we can predict the probability that an individual will play the lottery on the basis of the gambling behavior of their fellow household members. Felsher et al. (2003) have found that parents' lottery gambling behavior explains why young household members start and continue participating in the game.

The selection effect has to be distinguished from the causal effect of the social surroundings: the gambling behavior of individuals with whom people have close ties could influence the decision to start or to continue playing the lottery. It has been shown that people play in syndicates together with others for social reasons, e.g. for the purpose of maintaining friendship and group life (Garvía 2007; Guillén et al. 2012; Humphreys and Perez 2013). Playing the lottery in a group allows for shared experiences, enforces common values, and encourages communication. In this sense, it can be seen as a "groupbuilding activity" (Binde 2009:17). Since it produces these social values, the utility of a lottery ticket exceeds the expected monetary return (Beckert and Lutter 2013). One can also obtain these positive social returns without playing in a syndicate. If one's close ties play the lottery, it is likely that the lottery becomes a topic of conversation or a social event even if the players play separately. Thus, it can be assumed that people at least partly play the lottery on social grounds.

The above arguments have been concerned with individuals' decisions to play the lottery. Yet, we also expect that the same arguments hold for people's expenditures on lottery tickets. Social contagion may influence expenditures since individuals in one's social network, who also play the lottery, may encourage one to spend more money on lottery tickets. Further, if people play in syndicates, they will do so regularly, as a result of which their expenditures will be higher than those of gamblers who play in isolation. In addition, if people play the lottery for social reasons, reducing expenditures (e.g., after losses) could threaten the continuity of the group or one's own group membership and are therefore less likely (Beckert and Lutter 2013).

\section{Belief in Good Luck and the Imaginative Qualities of Lottery Play}

Another approach to explaining lottery gambling is based on Campbell's (1987) consumption theory and Beckert's (2016) theory of fictional expectations. From this perspective, people do not buy lottery tickets as an economic investment, but to buy daydreams about positive social futures, e.g. evocations of immense wealth, a higher social status, or improved life opportunities (Lutter 2012). According to Campbell (1987:89), in modern societies "individuals do not so much seek satisfaction from products, as pleasure from the self-illusory experience which they construct from their associated meanings." Having a lottery ticket in hand, the player can enjoy daydreaming about becoming rich.

Kocher et al. (2014) designed an experiment that demonstrates that "buying a dream" is a motivation for playing the lottery. Participants in the experiment could choose whether they wanted to have a lottery ticket for the same or the following day. Those participants who preferred a delayed lottery ticket were more likely to experience emotions such as hope and the thrill of anticipation. In this sense, playing the lottery involves consumption benefits like daydreaming and fantasizing about a positive future (Binde 2013; Forrest et al. 2002). 


\section{Deprivation or Strain Theory}

According to structural functionalist and deprivation theories, playing the lottery can also be perceived as a form of tension or strain management (Bloch 1951; Devereux 1980). Modern societies create pressure to be successful, but the means to achieve success are unequally distributed, leading to frustrations for many (Frey 1984; Merton 1938). Gambling can relieve tensions felt by individuals who are frustrated by their social status or because they feel generally alienated. Dissatisfaction with one's daily work routines or status inconsistencies are causes of this kind of strain. Gambling releases these tensions in different ways. First, it helps one escape the monotony of everyday life (Goffman 1967). In this sense, playing the lottery can be perceived as a leisure activity in which people buy tickets to enjoy the fun and thrill of the game (Burger et al. 2016; Casey 2006; Downes et al. 1976; Kocher et al. 2014). Second, although the chances of winning are low, playing the lottery at least creates hope for material improvement and a higher social status that cannot be achieved through conventional channels (Beckert and Lutter 2013; Bloch 1951; Clotfelter and Cook 1991; Devereux 1980; Forrest et al. 2002). And third, hearing stories about lottery winners can help relieve strain. When one has a ticket, "the process of identification with these lucky persons is greatly facilitated" (Devereux 1980:782). One might envy the winner, but it can nevertheless be satisfying to see that the lottery wins were distributed by chance. "Lotteries may be considered a 'social equalizer' in that, no matter what your position in society, everyone has an equal chance to win" (Haisley et al. 2008:289). And again, there is the hope that one might be the winner oneself next time.

Therefore, we assume that playing the lottery relieves feelings of strain resulting from an unsatisfactory daily life or status inconsistencies. Greco and Curci (2016) show that feelings of strain are related to both gambling and substance abuse. Friehe and Mechtel (2015) suggest that status orientation is related to gambling behavior. They find that households that are concerned with status are more likely to participate in gambling and spend more on it (lotteries, betting shops, casinos, gaming machines, and online betting). Haisley et al. (2008) designed an experiment to investigate whether implicit comparisons with other income classes increase the probability of playing the lottery. The participants, all of whom were low-income individuals, were divided into two groups and had to report their income. One group was given a range of income brackets that placed their income near the bottom, while the other was given a range that made them appear relatively better off. The researchers found that people who are made to feel poor are more likely to purchase lottery tickets.

We argue that it is not only the subjectively perceived social status that is important, but also the change in social position relative to one's past. If one's own situation has gotten worse, feelings of deprivation may arise or become more intense. We expect that the greater the deprivation, the higher the subsequent stakes in the lottery gambling activity.

A satisfaction with work ethical values could reduce the temptation to play the lottery. While a work ethic emphasizes productivity, efficiency, and self-discipline, playing the lottery contradicts these virtues by ignoring rationality and self-reliance (Beckert and Lutter 2013). We assume that playing the lottery is especially effective for strain management for people who are dissatisfied with work ethical values, since those people might not believe they can change their life for the better through their own hard work. 


\section{Hypotheses}

Deriving from the three sociological approaches, we test the following hypotheses:

H1.1 A person is more likely to play the lottery if someone else in their household does so as well.

H1.2 Playing the lottery in a syndicate increases the probability of playing the lottery more regularly.

H1.3 A person will spend more on lottery gambling if someone else in the household also plays the lottery.

H1.4 A person's lottery expenditures will be higher if they play the lottery in a syndicate.

H2.1 The more a person expresses beliefs in good luck and daydreams about a positive future, the higher the probability to play the lottery.

H2.2 The more a person expresses beliefs in good luck and daydreams about a positive future, the higher the expenditures on the lottery.

H3.1 The higher a person's dissatisfaction with their work and social status, the higher the probability to play the lottery.

H3.2 The higher a person's dissatisfaction with their work and social status, the higher the expenditures on the lottery.

H3.3 The more that a person's income has recently decreased, the higher the probability to play the lottery.

H3.4 The more a person's income has recently decreased, the higher the expenditures on the lottery.

\section{Methods}

\section{Participants and Setting}

To explore the social factors behind lottery play, we draw on data from a nationwide survey and make use of its panel and household structure data. The German Socio-Economic Panel Innovation Sample (SOEP-IS) is a specific module of the German SocioEconomic Panel, a representative panel survey of the German population. The SOEP-IS is a random sample of households. Within a selected household, every member of a household above age 17 is asked to answer a questionnaire separately. The SOEP-IS was established for particularly innovative research projects and thus differs from the SOEP Core Study because of the additional modules it uses. ${ }^{1}$ In 2014, the SOEP-IS included the module "Lottery Play: Expenditure, Frequency, and Explanatory Variables." This module was implemented for this particular study and measures lottery play and possible explanatory variables. Besides providing representative data on the prevalence of lottery play, the module makes it possible to test social factors of lottery play in a large-scale,

\footnotetext{
${ }^{1}$ For data access, see SOEP-IS (2014). For more information on SOEP-IS, see Richter and Schupp (2012).
} 
nationally representative study. In addition to the data on lottery play, which is representative for the year 2014, the module makes it possible to use the specific panel structure of the SOEP-IS core modules. While data on lottery play is only available from the 2014 study, we use sociodemographic data from the 2013 and 2014 SOEP-IS core modules, which allows us to test whether changes in personal income affect lottery play (as a test for strain theory). The main sample (SOEP-IS 2014) consists of 3730 households, containing a total of 5868 individuals. $53.1 \%$ of the participants are female. The average age of the participants is 52 years, with ages ranging from 17 to 96 years.

\section{Instruments}

To measure lottery play we use the following item: "How often do you usually play the lottery? (1) At least once a week; (2) At least once or twice a month; (3) A few times year; (4) I don't play." The following item measures the expenditures: "How much money did you spend on lottery tickets within the last month?" (in Euro). Both items have been used and quality-tested in previous studies (Beckert and Lutter 2009, 2013). To operationalize work/life satisfaction we use two items taken from a scale by Firestone et al. (2005): "I think my daily life or job is much more interesting than those of others" and "I'm often bored during the day" (seven-point Likert scale from $1=$ "I fully agree" to $7=$ "I don't agree at all"). The seven-point Likert items measuring work orientation are taken from a scale by Mirels and Garrett (1971) and read: "If one works hard enough, one is likely to make a good life for oneself" and "The self-made person is likely to be more ethical than the person born to wealth" (reverse coded).

The predisposition to daydreaming and beliefs in good luck are measured by the following seven-point Likert items: "I often dream about what it would be like to win a large amount of money in the lottery", "I often indulge in daydreams about a positive future for myself", "In order to get along in life, it is good to have luck on your side", and "Life is mostly controlled by fate" (Beckert and Lutter 2013).

\section{Variables}

Our main dependent variables are, first, a binary coded variable that measures whether a respondent plays the lottery at least a few times a year or does not play at all $(1=$ respondent played at least a few times a year; $0=$ otherwise), and second, the amount he or she spends on lottery tickets each month. The latter measures the intensity with which they play the lottery. Further dependent variables are used to check the robustness of our findings. We distinguish between the frequency of lottery play by using two more binary coded variables: playing at least once or twice a month and playing weekly. To capture the degree of financial involvement in lottery gambling, we use monthly expenditures as a percentage share of income (Beckert and Lutter 2013). In addition, we use the logged expenditure for lottery tickets because expenditures are highly skewed and a natural log transformation would allow the linear model to fit well.

To test the hypotheses regarding social network effects (H1.1-H1.4), we use two binary coded explanatory variables. One measures whether at least one other household member plays the lottery $(1=$ at least one other household member plays; $0=$ none of the other household members play/single-person household). To build this variable, we do not have to rely on egocentric networks, but instead can take advantage of the household-based study. If another member of the respondent's household indicated that they play the lottery at least a few times a year, the variable is coded 1 . If no other household member indicated 
that they play or if the respondent lives in a single-person household, the variable is coded 0 . The second variable measures whether the respondent usually plays in a syndicate ( $1=$ usually plays with others, $0=$ usually plays alone). Since this question was only asked if the respondent indicated that they play the lottery, we have missing values for those respondents who do not play the lottery at least a few times a year.

To test the hypotheses regarding the imaginative qualities of lottery play $(\mathrm{H} 2.1, \mathrm{H} 2.2)$ and to test strain theory (H3.1, H3.2), we rely on predicted factor scores of an iterated principal factor analysis (see "Results" section). The aim of the factor analysis is to summarize measures of work satisfaction, work orientation, predisposition to daydreaming, and beliefs in good luck.

In addition, we test strain theory by looking at the respondents' change in income. Here, we make use of the panel structure of the SOEP-IS and build a variable by subtracting the equivalized income in 2014 from that in 2013. Thus, the decline in a respondent's equivalized income (in 100 euros) is used as another explanatory variable.

As control variables, we use age (in years), a binary coded variable for gender ( $1=$ female, $0=$ male), education (number of years spent in school and higher-learning institutions), a binary coded variable for the household type ( $1=$ single-person household, $0=$ otherwise), level of employment $(1=$ full time, $0=$ otherwise $)$, unemployed $(1=$ yes, $0=$ otherwise), retired $(1=$ yes, $0=$ otherwise), and income (monthly equivalized available net income in euros $\left.{ }^{2}\right)$.

\section{Statistical Methods}

In order to test our hypotheses, we estimate a series of regressions on lottery play and on monthly expenditures. First, we estimate logistic regressions since our measures for lottery play are binary coded. As dependent variables, we use lottery play (model 1), regular lottery play (model 2), and weekly lottery play (model 3). Respondents who stated that they do not play the lottery at all were not asked if they play in a syndicate. To test the association between playing in a syndicate and the probability of playing the lottery on a regular basis, we therefore only need to examine the respondents who indicated that they play at least a few times a year. Here, we again use regular lottery play (model 4) and weekly lottery play (model 5) as dependent variables and limit our sample to lottery players.

Second, we estimate an OLS regression on monthly expenditures in euros (model 6). To test non-linear relationships, we estimate an OLS regression on logged monthly expenditures (model 7). In model 8, we use expenditures as a percentage of equivalized income as the dependent variable. Since expenditures as a percentage of income are bounded between 0 and 1, we use a fractional response model (Papke and Wooldridge 1996). Respondents who indicated that they do not play the lottery were not asked how much they spend on lottery tickets. In models 6 to 8 , we include all respondents and assign 0 euros to those who do not play the lottery. Since $\ln (0)$ is not defined, we add a constant term to conduct the log transformation (Cameron and Trivedi 1998:90). We estimate $\ln (\mathrm{y}+1)$ by OLS in models 7 and 10. Since we want to estimate the association between playing in a syndicate and expenditures, we have to limit our sample to lottery players in the remaining

\footnotetext{
2 The equivalized income is calculated according to the OECD-modified equivalence scale. This scale assigns a value of 1 to the household head, a value of 0.5 to each additional adult household member (above age 14), and a value of 0.3 to each child (below age 14).
} 
models: In models 9 to 11 , we exclude all respondents who indicated that they do not play the lottery.

We use robust standard errors clustered on a variable indicating the household, because we expect that the errors associated with one respondent are correlated with those associated with other household members.

\section{Results}

\section{Factor Analysis}

We use factor analysis to create aggregates that summarize measures of work satisfaction and work orientation, predisposition to daydreaming and beliefs in good luck. The result of an iterated principal factor analysis over nine items suggests assuming two latent factors (eigenvalues of 1.2 and 0.8$){ }^{3}$ The items and the rotated factor loadings are presented in Table 1. The first eight items are measured on a seven-point Likert scale ( $1=$ "I fully agree" to $7=$ "I don't agree at all"), the last item on an eleven-point Likert scale $(0=$ low to $10=$ high $)$. To make the result easy to interpret, we recoded four items in reverse (see Table 1). The factorability of the data is tested with the Kaiser-Meyer-Olkin criterion of sampling adequacy. Every item has a value above 0.60 , and the overall value of the Kaiser-Meyer-Olkin criterion is 0.64. According to Kaiser (1974), these values are mediocre. There are no cross-loadings if we consider the value 0.3 as the threshold. To allow the two factors to be correlated, we use oblique rotation. Measures of belief in good luck and the tendency to daydream load on the first factor (factor loadings between 0.41 and 0.56). Factor loadings represent the correlation between the items and the latent factors. Thus, the items measuring belief in good luck and the tendency to daydream correlate with the first latent factor. We predict factor scores for each respondent and use these scores as a variable to test the hypotheses regarding the imaginative qualities of lottery play $(\mathrm{H} 2.1, \mathrm{H} 2.2)$. High values on this factor score variable indicate that the respondent believes in good luck and dreams about a better future. Items measuring income and work satisfaction as well as work orientation load on the second factor (factor loadings between 0.33 and 0.44 ). Again, we create a variable based on the predicted factor scores. The higher the value on this variable, the higher the dissatisfaction with one's household income, with one's daily work routines, and with positive orientations towards work. We use this scale to test strain theory (H3.1, H3.2).

\section{Descriptive Data}

Table 2 gives descriptive statistics of the dependent variables across some sociodemographic characteristics: $24.8 \%$ of the respondents play the lottery at least a few times a year, $15.9 \%$ play at least once or twice a month, and $11.7 \%$ play weekly. On average, a lottery player spends $€ 22.04$ per month on lottery tickets or $1.5 \%$ of their income. Male respondents play more often and spend more than female respondents. Respondents with a higher income play more often but spend proportionally less of their income on lottery tickets. Respondents above the age of 59 play more regularly and spend more, both in

\footnotetext{
${ }^{3}$ Results of the Scree test and the big gap between the eigenvalues of the second (0.8) and third factors (0.3) indicate that there are two latent variables.
} 
Table 1 Rotated factor loadings

\begin{tabular}{llll}
\hline Variable & $\begin{array}{l}\text { Factor } \\
1\end{array}$ & $\begin{array}{l}\text { Factor } \\
2\end{array}$ & Uniqueness \\
\hline $\begin{array}{l}\text { "I often dream about what it would be like to win a large amount of } \\
\text { money in the lottery" }\end{array}$ & 0.41 & & 0.81 \\
$\begin{array}{l}\text { "I often indulge in daydreams about a positive future for myself" } \\
\text { "In order to get along in life, it is good to have luck on your side" }\end{array}$ & 0.41 & 0.56 & 0.83 \\
$\begin{array}{l}\text { "Life is mostly controlled by fate" } \\
\text { "I think my daily life or job is much more interesting than those of } \\
\text { others" (reverse coded) }\end{array}$ & 0.55 & 0.68 \\
$\begin{array}{l}\text { "I'm often bored during the day" } \\
\text { "If one works hard enough, one is likely to make a good life for oneself" } \\
\text { (reverse coded) }\end{array}$ & & 0.42 & 0.70 \\
"The self-made person is likely to be more ethical than the person born to & & 0.39 & 0.74 \\
$\quad \begin{array}{l}\text { wealth" (reverse coded) } \\
\text { Satisfaction with household income (reverse coded) }\end{array}$ & 0.79 & 0.78 \\
\hline
\end{tabular}

Results of an iterated principal factor analysis, oblique quartimin rotation method

Factor loadings $<0.3$ are not shown

absolute terms and relative to their income, than younger respondents. Tables 3 and 4 present descriptive statistics of the explanatory and control variables.

\section{Regression Analyses}

Table 5 presents the results of the logistic regressions. The dependent variables are binary coded variables measuring the frequency of lottery play. In model 1 , we use a variable that distinguishes whether a person plays at least a few times a year or not at all; in model 2 whether a person plays at least once or twice a month; and in model 3 whether a person plays weekly. In models 4 and 5, the sample is limited to lottery players. The results are largely robust to these different model specifications. Sex, age, income, and employment status are significant predictors of the probability of playing the lottery.

Consistent with our first hypotheses, we find social networks effects. The odds of playing the lottery are significantly higher for persons who have at least one household member who plays the lottery. Holding everything else equal, the odds of playing the lottery for people who have a household member who plays are 3.6 times higher than for people who do not. The item measuring whether a respondent plays in a syndicate was only asked if the respondent indicated that they play the lottery at least a few times a year. Therefore, we include the variable syndicate play only in models 4 and 5 . The probability of playing the lottery regularly or even weekly is significantly higher for lottery players who usually play in a syndicate. These results suggest that we can predict the probability that an individual plays the lottery by looking at their social surroundings. However, we cannot separate the causal effect from the selection effect in this study empirically.

The results of models 1, 2, and 3 show a significant positive association between the daydream scale and the probability of playing the lottery. This is in line with hypothesis H2.1. Ceteris paribus, the more one expresses a belief in good luck and daydreams about a positive future, the higher the odds of playing the lottery. 
Table 2 Descriptive statistics of dependent variables across sociodemographic characteristics

\begin{tabular}{|c|c|c|c|c|c|c|}
\hline & $\begin{array}{l}\text { Lottery } \\
\text { players }^{\mathrm{a}} \text { (in } \\
\% \text { ) }\end{array}$ & $\begin{array}{l}\text { Regular } \\
\text { lottery } \\
\text { players } \\
\text { (in \%) }\end{array}$ & $\begin{array}{l}\text { Weekly } \\
\text { lottery } \\
\text { players (in } \\
\% \text { ) }\end{array}$ & $\begin{array}{l}\text { Monthly } \\
\text { expenditures } \\
\text { of lottery } \\
\text { players (mean } \\
\text { in } € \text { ) }\end{array}$ & $\begin{array}{l}\text { Logged } \\
\text { monthly } \\
\text { expenditures } \\
\text { of lottery } \\
\text { players }\end{array}$ & $\begin{array}{l}\text { Monthly } \\
\text { expenditures as a } \\
\text { percentage share } \\
\text { of income (in \%) }\end{array}$ \\
\hline \multicolumn{7}{|l|}{ Gender } \\
\hline Male & 29.7 & 19.8 & 14.4 & 23.94 & 2.54 & 1.6 \\
\hline Female & 20.2 & 12.4 & 9.3 & 19.47 & 2.30 & 1.4 \\
\hline \multicolumn{7}{|c|}{ Monthly equivalized available net income } \\
\hline 1st Quintile & 21.0 & 12.1 & 6.9 & 20.74 & 2.20 & 2.8 \\
\hline 2nd Quintile & 22.3 & 14.3 & 10.1 & 20.36 & 2.35 & 1.7 \\
\hline 3rd Quintile & 27.5 & 17.6 & 13.3 & 20.90 & 2.39 & 1.4 \\
\hline 4th Quintile & 27.7 & 18.5 & 15.3 & 22.12 & 2.48 & 1.1 \\
\hline 5th Quintile & 26.9 & 17.5 & 13.5 & 25.44 & 2.65 & 0.9 \\
\hline \multicolumn{7}{|l|}{ Age } \\
\hline $\begin{array}{c}17-33 \\
\text { Years }\end{array}$ & 12.2 & 4.0 & 1.8 & 12.19 & 1.63 & 0.9 \\
\hline $\begin{array}{l}34-48 \\
\text { Years }\end{array}$ & 25.1 & 12.5 & 7.9 & 16.53 & 2.08 & 1.2 \\
\hline $\begin{array}{c}\text { 49-58 } \\
\text { Years }\end{array}$ & 28.6 & 18.5 & 13.1 & 20.17 & 2.43 & 1.2 \\
\hline $\begin{array}{l}59-70 \\
\text { Years }\end{array}$ & 32.4 & 23.8 & 18.7 & 27.04 & 2.67 & 2.0 \\
\hline$>71$ Years & 25.9 & 21.7 & 18.0 & 27.93 & 2.93 & 1.9 \\
\hline $\begin{array}{l}\text { In total, } \\
\text { frequency } \\
\text { in } \\
\text { brackets }\end{array}$ & $24.8(1450)$ & 15.9 (933) & $11.7(689)$ & 22.04 & 2.44 & 1.5 \\
\hline
\end{tabular}

$\mathrm{N}=5858$

${ }^{\text {a }}$ Lottery players: play at least a few times a year

${ }^{\mathrm{b}}$ Regular lottery players: play at least once or twice a month

Table 3 Descriptive statistics of all continuous dependent and independent variables

\begin{tabular}{lrrrrr}
\hline Variable & N & Mean & \multicolumn{1}{c}{$\begin{array}{l}\text { Std. } \\
\text { Dev }\end{array}$} & Min. & Max. \\
\hline Age & 5868 & 51.79 & 18.31 & 17 & 96 \\
Education (years) & 5742 & 12.24 & 2.65 & 7 & 18 \\
Equivalized income & 5529 & 1692.19 & 876.42 & 200 & 10,476 \\
Decline in income (difference equivalized income & 3942 & -30.14 & 525.41 & -5714 & $12,666.67$ \\
$\quad$ SOEP-IS 2013-2014) & & & & & \\
Daydream scale (Factor 1) & 5326 & 0.00 & 0.75 & -2.24 & 2.5 \\
Work-dissatisfaction scale (Factor 2) & 5326 & 0.00 & 0.67 & -2.88 & 1.5 \\
\hline
\end{tabular}


Table 4 Descriptive statistics of all categorical dependent and independent variables

\begin{tabular}{lll}
\hline Variable & N & Percentage of the sample \\
\hline Single-person household & 5859 & 22.1 \\
Female & 5868 & 52.1 \\
Employment full time & 5868 & 34.4 \\
Retired & 5768 & 30.5 \\
Unemployed & 4707 & 7.5 \\
Other household member plays the lottery & 5864 & 18.1 \\
Syndicate play & 1447 & 25.9 \\
\hline
\end{tabular}

Concerning strain theory, the results are ambiguous. When looking at the probability of playing the lottery, differences in one's equivalized income from 2013 to 2014 have no significant effect. Nevertheless, the coefficient is positive, indicating that a decline in income might be associated with a higher probability of playing the lottery. The workdissatisfaction scale is significantly positively associated with the probability of playing the lottery at least a few times a year. Holding everything else constant, the more that a person is dissatisfied with their household income, or with their daily work routines and orientations towards work, the higher the probability that they play the lottery at least a few times a year. If a person already plays the lottery at least a few times a year, it seems that there is no further association between work dissatisfaction and how often they play the lottery.

Table 6 presents the results of the regressions on expenditures. The adjusted $R^{2}$ is higher for the models with logged expenditures indicating non-linear relationships. Gender, age, and income are significant predictors of expenditures on lottery tickets.

Here, similarly to the results of the regressions on the probability of playing the lottery, we find some social network effect. Ceteris paribus, persons who have at least one other person in the household who plays the lottery spend on average $€ 7.19$ a month more on lottery tickets than persons without household members who play the lottery. If we look only at the lottery players, this effect is reduced to €6.40 a month. However, playing in a syndicate is not significantly related to expenditures.

Regarding the imaginative qualities of lottery play, we find support for our hypothesis. Including all respondents, there is a significant positive association between the daydream scale and all three specifications of expenditures. If we exclude respondents who play less than a few times a year, only the coefficient in the model with logged expenditures remains significant. However, the coefficients in the two other models are still positive.

We also find support for our hypotheses regarding strain theory. A decline in a person's equivalized income is significantly accompanied by an increase in their expenditures on lottery tickets. This result is robust for all model specifications and the inclusion or exclusion of respondents who play less than a few times a year. Lottery expenditures can be seen as a means of correcting for low-income status relative to one's past income status. In contrast, the work-dissatisfaction scale is not significantly related to expenditures on lottery tickets. 
Table 5 Results lottery play

\begin{tabular}{|c|c|c|c|c|c|}
\hline & $\begin{array}{l}\text { (1) } \\
\text { Lottery } \\
\text { play }\end{array}$ & $\begin{array}{l}(2) \\
\text { Regular } \\
\text { Lottery } \\
\text { Play }\end{array}$ & $\begin{array}{l}(3) \\
\text { Weekly } \\
\text { Lottery } \\
\text { Play }\end{array}$ & $\begin{array}{l}\text { (4) } \\
\text { Regular Lottery } \\
\text { Play (only lottery } \\
\text { players) }\end{array}$ & $\begin{array}{l}\text { (5) } \\
\text { Weekly Lottery } \\
\text { Play (only lottery } \\
\text { players) }\end{array}$ \\
\hline $\begin{array}{l}\text { Daydream scale } \\
\text { (Factor 1) }\end{array}$ & $\begin{array}{l}0.46 * * * \\
(8.15)\end{array}$ & $\begin{array}{l}0.53 * * * \\
(7.56)\end{array}$ & $\begin{array}{l}0.50 * * * \\
(6.26)\end{array}$ & $\begin{array}{l}0.32 * * \\
(3.11)\end{array}$ & $\begin{array}{l}0.23^{*} \\
(2.20)\end{array}$ \\
\hline $\begin{array}{l}\text { Work-dissatisfaction } \\
\text { scale (Factor 2) }\end{array}$ & $\begin{array}{l}0.12 * \\
(1.98)\end{array}$ & $\begin{array}{l}0.06 \\
(0.83)\end{array}$ & $\begin{array}{l}0.02 \\
(0.20)\end{array}$ & $\begin{array}{l}-0.07 \\
(-0.59)\end{array}$ & $\begin{array}{l}-0.10 \\
(-0.92)\end{array}$ \\
\hline $\begin{array}{l}\text { Difference } \\
\text { equivalized income } \\
\text { 2013-2014 (/100) }\end{array}$ & $\begin{array}{l}0.01 \\
(1.00)\end{array}$ & $\begin{array}{l}0.01 \\
(1.22)\end{array}$ & $\begin{array}{l}0.01 \\
(1.10)\end{array}$ & $\begin{array}{l}0.01 \\
(0.77)\end{array}$ & $\begin{array}{l}0.01 \\
(0.68)\end{array}$ \\
\hline $\begin{array}{l}\text { Other household } \\
\text { member plays }\end{array}$ & $\begin{array}{l}1.29 * * * \\
(9.82)\end{array}$ & $\begin{array}{l}1.39 * * * \\
(9.87)\end{array}$ & $\begin{array}{l}1.39 * * * \\
(9.11)\end{array}$ & $\begin{array}{l}0.46^{*} \\
(2.28)\end{array}$ & $\begin{array}{l}0.54 * * \\
(2.78)\end{array}$ \\
\hline $\begin{array}{l}\text { Single-person } \\
\text { household }\end{array}$ & $\begin{array}{l}0.41 * * * \\
(3.79)\end{array}$ & $\begin{array}{l}0.49 * * * \\
(3.89)\end{array}$ & $\begin{array}{l}0.47 * * \\
(3.28)\end{array}$ & $\begin{array}{l}0.35^{+} \\
(1.74)\end{array}$ & $\begin{array}{l}0.27 \\
(1.45)\end{array}$ \\
\hline Female & $\begin{array}{l}-0.48^{* * *} \\
(-5.20)\end{array}$ & $\begin{array}{l}-0.49 * * * \\
(-4.89)\end{array}$ & $\begin{array}{l}-0.42 * * * \\
(-3.79)\end{array}$ & $\begin{array}{l}-0.18 \\
(-1.15)\end{array}$ & $\begin{array}{l}-0.05 \\
(-0.34)\end{array}$ \\
\hline Age & $\begin{array}{l}0.02 * * * \\
(7.22)\end{array}$ & $\begin{array}{l}0.04 * * * \\
(9.04)\end{array}$ & $\begin{array}{l}0.04 * * * \\
(8.55)\end{array}$ & $\begin{array}{l}0.05 * * * \\
(6.96)\end{array}$ & $\begin{array}{l}0.05 * * * \\
(6.66)\end{array}$ \\
\hline Education (years) & $\begin{array}{l}0.02 \\
(1.18)\end{array}$ & $\begin{array}{l}0.02 \\
(0.81)\end{array}$ & $\begin{array}{l}0.00 \\
(0.03)\end{array}$ & $\begin{array}{l}0.01 \\
(0.19)\end{array}$ & $\begin{array}{l}-0.03 \\
(-0.78)\end{array}$ \\
\hline $\begin{array}{l}\text { Equivalized income (/ } \\
\text { 100) }\end{array}$ & $\begin{array}{l}0.01 \\
(1.50)\end{array}$ & $\begin{array}{l}0.01 * \\
(2.37)\end{array}$ & $\begin{array}{l}0.02 * * * \\
(3.59)\end{array}$ & $\begin{array}{l}0.03 * \\
(2.21)\end{array}$ & $\begin{array}{l}0.04 * * * \\
(3.73)\end{array}$ \\
\hline Employment, full time & $\begin{array}{l}0.23^{*} \\
(1.98)\end{array}$ & $\begin{array}{l}0.31 * \\
(2.18)\end{array}$ & $\begin{array}{l}0.45 * * \\
(2.69)\end{array}$ & $\begin{array}{l}0.33 \\
(1.56)\end{array}$ & $\begin{array}{l}0.51^{*} \\
(2.39)\end{array}$ \\
\hline Retired & $\begin{array}{l}-0.23^{+} \\
(-1.66)\end{array}$ & $\begin{array}{l}-0.16 \\
(-0.95)\end{array}$ & $\begin{array}{l}0.03 \\
(0.14)\end{array}$ & $\begin{array}{l}0.07 \\
(0.26)\end{array}$ & $\begin{array}{l}0.29 \\
(1.22)\end{array}$ \\
\hline Unemployed & $\begin{array}{l}-0.27 \\
(-1.29)\end{array}$ & $\begin{array}{l}-0.47^{+} \\
(-1.72)\end{array}$ & $\begin{array}{l}-0.36 \\
(-1.08)\end{array}$ & $\begin{array}{l}-0.23 \\
(-0.61)\end{array}$ & $\begin{array}{l}0.10 \\
(0.24)\end{array}$ \\
\hline Syndicate play & & & & $\begin{array}{l}0.89 * * * \\
(4.20)\end{array}$ & $\begin{array}{l}0.55 * * \\
(2.82)\end{array}$ \\
\hline Constant & $\begin{array}{l}-2.84 * * * \\
(-10.57)\end{array}$ & $\begin{array}{l}-4.40 * * * \\
(-12.89)\end{array}$ & $\begin{array}{l}-5.13 * * * \\
(-12.61)\end{array}$ & $\begin{array}{l}-3.30 * * * \\
(-5.20)\end{array}$ & $\begin{array}{l}-4.01 * * * \\
(-6.38)\end{array}$ \\
\hline McFadden $\mathrm{R}_{\text {Pseudo }}^{2}$ & 0.09 & 0.12 & 0.13 & 0.14 & 0.13 \\
\hline Log-likelihood & -1847.75 & -1423.90 & -1177.03 & -513.04 & -560.08 \\
\hline AIC & 3721.50 & 2873.80 & 2380.06 & 1054.09 & 1148.17 \\
\hline $\mathrm{BIC}$ & 3801.58 & 2953.88 & 2460.15 & 1121.73 & 1215.82 \\
\hline $\mathrm{N}$ & 3498 & 3498 & 3500 & 927 & 927 \\
\hline
\end{tabular}

Logistic regression models on different dependent variables, $t$ statistics in parentheses; in models 4 and 5 the sample is limited to respondents who play at least a few times a year

${ }^{+} p<0.1 ; * p<0.05 ; * * p<0.01 ; * * * p<0.001$ (two-tailed tests)

\section{Discussion}

This article examines the social contexts of gambling and the social motivations for playing the lottery. Recognizing that playing the lottery is a multidimensional phenomenon, we test three sociological approaches simultaneously: network effects, 


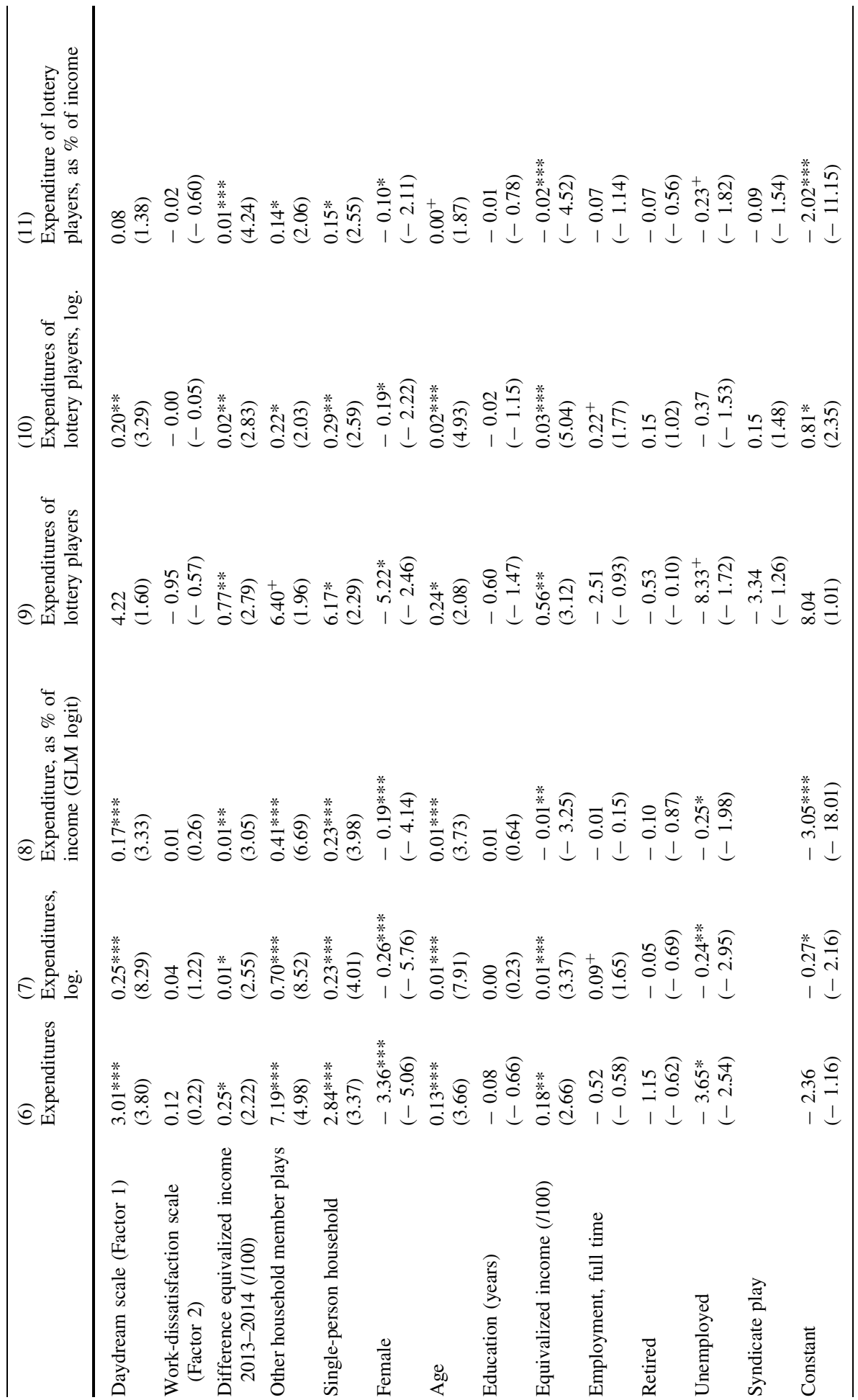




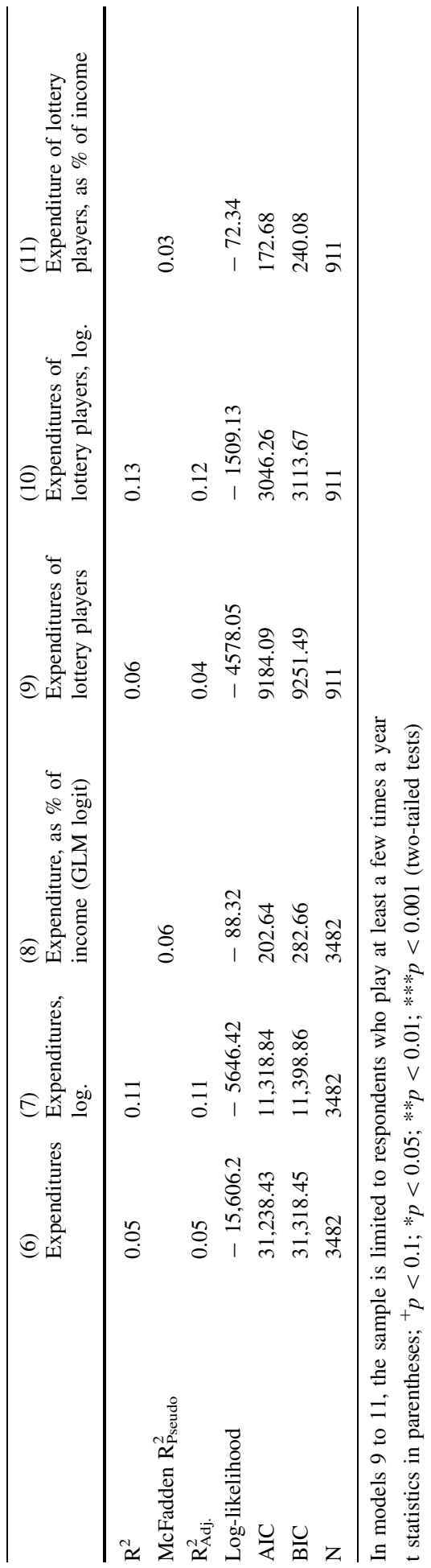


consumption theory, and strain theory. The data used (SOEP-IS) has several advantages beyond providing a representative sample of the German population. With information on all household members, we can analyze social network effects while avoiding the problems of egocentric network data. Another benefit of the SOEP-IS is the panel structure. Although we have no longitudinal information on gambling behavior, we use the panel structure to build an explanatory variable: we improve the measurement of status inconsistencies by using the decline in income as a measure for them.

We test social network effects by looking at both the effect of syndicate play and the effect of having lottery players in the household on the probability to play the lottery as well as on expenditures. We find that people who play in a syndicate play more regularly but do not spend significantly more money on lottery tickets than players who gamble individually. Prior studies find similar results with Spanish and US data. Humphreys and Perez (2013) analyze different Spanish lottery games and find that syndicate participants play the lottery more frequently than individual players but find no consistent pattern regarding expenditures. Garvía (2007) finds that also American syndicate players play more frequently than individual players. Although they find that American syndicate players spend more money on lottery tickets than individual one, the difference is not statistically significant. However, with German data from 2006, Beckert and Lutter (2013) find that syndicate players spend significantly more on lottery tickets than participants who usually play alone or not at all.

These results point to the social benefits individuals derive from lotteries. They have to play and meet regularly, but it is enough to spend a few euros on a syndicate ticket to enjoy an emotional experience with like-minded people. This interpretation is strengthened by findings that socially and fun motivated lottery players are happier than non-players as well as only-for-money players (Burger et al. 2016). At the same time, our results indicate that playing the lottery could also be the result of social contagion. Having another person in the household who plays the lottery is positively associated with both the probability of playing (regularly) and how much one spends on lottery tickets. These results confirm findings from prior studies that rely on egocentric networks and that partly use nonrepresentative data. Beckert and Lutter (2013) show a significant and positive association between the lottery play of a respondent's close network (friends, partner, and parents) and expenditures. Felsher et al. (2003) report that Canadian adolescents, especially females, indicate playing the lottery in particular because of parental participation. Browne and Brown (1994) show with student data that playing the lottery is related to having parents and friends who play the lottery. Welte et al. (2017) do not look at behavior of the social network but attitudes and find that having friends who approve of gambling is significantly associated with problem gambling. However, the approval of the family is not significantly related with problem gambling, indicating a selection effect. In contrast, the significant association between lottery play of household members and respondents' probability to play as well as expenditures in our study points to social contagion. For household members, it is not necessary to play the lottery in order to meet more often and have shared experiences. It therefore seems reasonable to suppose that the statistical association is due to social contagion (e.g., imitation) and not selection. If so, the positive associational effects the lottery produces disappear while the negative effects remain. Social contagion is especially problematic for low-income members of society, since they spend more on lottery tickets relative to their income (see Table 2). However, a limitation of our study design is that we cannot clearly separate the selection effect from social contagion. Future research should address the question of whether the associations of social network 
variables and lottery play are due to selection effects or social contagion. In addition, it should be examined if social contagion is in particular effective for low-income households.

Apart from network-related factors, the daydream scale is a strong predictor of both the probability of playing and how much one spends. Only a few studies exist that test the imaginative qualities of lottery play. Forrest et al. (2002) develop a lotto demand model that comprise a consumption benefit of lottery tickets. They test their model with data from the U.K. National Lottery and conclude that buying a dream is an important factor for lotto demand and thus an important explanation for buying lottery tickets. In an experimental setting, Kocher et al. (2014) examine how individuals react to lottery participation. Participants could choose between a realization of the lottery with or without delay. They show that positive anticipatory emotions experienced while waiting for the resolution explain the choice of delayed resolution. This points to consumption benefits (e.g., daydreaming) of lottery play. Our study complements these findings with representative survey data. Applying three different approaches to test the theory, all three studies emphasize the imaginative qualities of lottery play. Lottery tickets should not only be seen as a monetary investment, but also as a consumption good: some lottery players are buying daydreams.

Regarding strain theory, our results are ambiguous. The effect of the work-dissatisfaction scale is not robust across different model specifications. We find that a decline in income is significantly related to expenditures, but not to the probability of playing the lottery (the coefficient is still positive). However, Olason et al. (2015) find that Icelander who had financial difficulties due to the economic recession were 52\% more likely to buy lottery tickets than those who had no financial difficulties. If playing the lottery in fact functions as an outlet for strain, this could have severe consequences at the individual and societal level. On the one hand, playing the lottery could then be an alternative to individual effort for upward mobility, for example investment in education and community activities (Beckert and Lutter 2013). On the other hand, relieving strain might also be a positive effect of lottery play. It might help individuals to cope with difficult times. Hu et al. (2017) find that there are positive and negative consequences of playing the lottery for the health of Chinese sports lottery players. More research is needed to examine the individual and societal consequences of playing the lottery for individuals who are frustrated by their social status.

The main contribution of this article is its simultaneous testing of three sociological approaches with representative survey data of the German population. One clear implication of our analysis is that sociological approaches to explaining lottery play make an important contribution. People play the lottery depending on their social surroundings, their desire to participate in a world normally out of their reach, and the tensions they feel as a result of the distance between their aspirations and their actual social position. In addition to social explanations, the psychological literature regarding lottery play shows that irrational beliefs about probability, random events, and the chance of winning, belief in good luck, and personality traits (e.g., impulsivity) are associated with lottery play. Future research could examine both theoretically and empirically if social and psychological explanations interact with each other. Psychological research has found that belief in good luck is associated with fantasy proneness and positive expectations regarding the outcome of events that are related to luck (Darke and Freedman 1997; Day and Maltby 2003; Fluke et al. 2014). Thus, the theory of imaginative qualities of lottery could be integrated in the cognitive theory of gambling. Regarding strain theory, it can be expected that frustrated individuals are more prone to irrational beliefs than less frustrated 
individuals are. In addition, peer play could moderate the effect of personality traits on lottery play. Combining the cognitive theory of gambling with social network theory, strain theory and the imaginative social qualities of lottery play could help to give a fuller picture of lottery participation and expenditures and could lead to fruitful insights.

\section{Compliance with Ethical Standards}

Conflict of interest The authors declare that they have no conflict of interest.

Ethical Approval All procedures performed in studies involving human participants were in accordance with the ethical standards of the institutional and/or national research committee and with the 1964 Helsinki declaration and its later amendments or comparable ethical standards.

\section{References}

Adams, D. J. (1996). Playing the lottery. Social action, social networks and accounts of motive. Ph.D. Dissertation, Department of Sociology, University of Arizona.

Adams, D. J. (2001). My ticket, my 'self': Lottery ticket number selection and the commodification and extension of the self. Sociological Spectrum, 21(4), 455-477.

Ariyabuddhiphongs, V. (2011). Lottery gambling: A review. Journal of Gambling Studies, 27(1), 15-33. https://doi.org/10.1007/s10899-010-9194-0.

Ariyabuddhiphongs, V., \& Chanchalermporn, N. (2007). A test of social cognitive theory reciprocal and sequential effects: Hope, superstitious belief and environmental factors among lottery gamblers in Thailand. Journal of Gambling Studies, 23(2), 201-214. https://doi.org/10.1007/s10899-006-9035-3.

Beckert, J. (2016). Imagined futures. Fictional expectations and capitalist dynamics. Cambridge, MA: Harvard University Press.

Beckert, J., \& Lutter, M. (2009). The inequality of fair play: Lottery gambling and social stratification in Germany. European Sociological Review, 25(4), 475-488. https://doi.org/10.1093/esr/jcn063.

Beckert, J., \& Lutter, M. (2013). Why the poor play the lottery: Sociological approaches to explaining classbased lottery play. Sociology, 47(6), 1152-1170. https://doi.org/10.1177/0038038512457854.

Beyerlein, K., \& Sallaz, J. J. (2017). Faith's Wager: How religion deters gambling. Social Science Research, 62, 204-218. https://doi.org/10.1016/j.ssresearch.2016.07.007.

Binde, P. (2009). Gambling motivation and involvement. A review of social science research. Östersund: The Swedish National Institute of Public Health.

Binde, P. (2013). Why people gamble: A model with five motivational dimensions. International Gambling Studies, 13(1), 81-97.

Bloch, H. A. (1951). The sociology of gambling. American Journal of Sociology, 57(3), 215-221.

Browne, B. A., \& Brown, D. J. (1994). Predictors of lottery gambling among American college students. The Journal of Social Psychology, 134(3), 339-347.

Burger, M. J., Hendriks, M., Pleeging, E., \& van der Zwan, P. W. (2016). The silver linings of lottery play: Motivation and subjective well-being of British lottery participants. Applied Economics Letters. https:// doi.org/10.1080/13504851.2016.1153783.

Cameron, C. A., \& Trivedi, P. K. (1998). Regression analysis of count data. New York: Cambridge University Press.

Campbell, C. (1987). The romantic ethic and the spirit of modern consumerism. Oxford: Basil Blackwell.

Casey, E. (2006). Domesticating gambling: Gender, caring and the UK national lottery. Leisure Studies, 25(1), 3-16. https://doi.org/10.1080/02614360500150695.

Chiu, J., \& Storm, L. (2010). Personality, perceived luck and gambling attitudes as predictors of gambling involvement. Journal of Gambling Studies, 26(2), 205-227.

Clotfelter, C. T., \& Cook, P. J. (1991). Selling hope. State lotteries in America. Cambridge, MA: Harvard University Press.

Darke, P. R., \& Freedman, J. L. (1997). The belief in good luck scale. Journal of Research in Personality, 31(4), 486-511.

Day, L., \& Maltby, J. (2003). Belief in good luck and psychological well-being: The mediating role of optimism and irrational beliefs. The Journal of Psychology, 137(1), 99-110. https://doi.org/10.1080/ 00223980309600602.

Devereux, E. C. (1980). Gambling and the social structure: A sociological study of lotteries and horse racing in contemporary America. New York: Arno Press. 
Downes, D. M., Davies, B. P., David, M. E., \& Stone, P. (1976). Gambling, work and leisure. London: Routledge and Kegan Paul Ltd.

Felsher, J. R., Derevensky, J. L., \& Gupta, R. (2003). Parental influences and social modelling of youth lottery participation. Journal of Community \& Applied Social Psychology, 13(5), 361-377. https://doi. org/10.1002/casp.738.

Firestone, J. M., Garza, R. T., \& Harris, R. J. (2005). Protestant work ethic and worker productivity in a Mexican Brewery. International Sociology, 20, 27-44.

Fluke, S. M., Webster, R. J., \& Saucier, D. A. (2014). Methodological and theoretical improvements in the study of superstitious beliefs and behaviour. British Journal of Psychology, 105(1), 102-126. https:// doi.org/10.1111/bjop.12008.

Forrest, D., Simmons, R., \& Chesters, N. (2002). Buying a dream: Alternative models of demand for lotto. Economic Inquiry, 40(3), 485-496. https://doi.org/10.1093/ei/40.3.485.

Frey, J. H. (1984). Gambling: A sociological review. The Annals of the American Academy of Political and Social Science, 474(1), 107-121.

Friehe, T., \& Mechtel, M. (2015). Gambling to leapfrog in status? Review of Economics of the Household. https://doi.org/10.1007/s11150-015-9306-9.

Garvía, R. (2007). Syndication, institutionalization, and lottery play. American Journal of Sociology, 113(3), 603-652.

Goffman, E. (1967). Interaction ritual. Essays on face-to-face behavior. New York: Anchor Books.

Greco, R., \& Curci, A. (2016). Does the general strain theory explain gambling and substance use? Journal of Gambling Studies. https://doi.org/10.1007/s10899-016-9654-2.

Guillén, M. F., Garvía, R., \& Santana, A. (2012). Embedded play: Economic and social motivations for sharing lottery tickets. European Sociological Review, 28(3), 344-354. https://doi.org/10.1093/esr/ jcq068.

Haisley, E., Mostafa, R., \& Loewenstein, G. (2008). Subjective relative income and lottery ticket purchases. Journal of Behavioral Decision Making, 21, 283-295. https://doi.org/10.1002/bdm.

Hu, Y., Wang, B., Liu, L., Li, G., Huang, X., \& Guo, D. (2017). Is lottery playing always harmful? Development of the lottery playing health scale. Social Behavior and Personality: An International Journal, 45(9), 1563-1571.

Humphreys, B. R., \& Perez, L. (2013). Syndicated play in lottery games. The Journal of Socio-Economics, 45, 124-131. https://doi.org/10.1016/j.socec.2013.05.010.

Kaiser, H. F. (1974). An index of factorial simplicity. Psychometrika, 39(1), 31-36. https://doi.org/10.1007/ BF02291575.

Kocher, M. G., Krawczyk, M., \& van Winden, F. (2014). 'Let me dream on!' Anticipatory emotions and preference for timing in lotteries. Journal of Economic Behavior \& Organization, 98, 29-40. https:// doi.org/10.1016/j.jebo.2013.12.006.

Ladouceur, R., Dube, D., Giroux, I., Legendre, N., \& Gaudet, C. (1995). Cognitive biases in gamblingAmerican Roulette and 6/49-Lottery. Journal of Social Behavior and Personality, 10(2), 473-479.

Lutter, M. (2012). Tagträume und Konsum. Die imaginative Qualität von Gütern am Beispiel der Nachfrage für Lotterien. Soziale Welt, 63(3), 233-251.

McPherson, M., Smith-Lovin, L., \& Cook, J. M. (2001). Birds of a feather: Homophily in social networks. Annual Review of Sociology, 27(1), 415-444.

Merton, R. K. (1938). Social structure and anomie. American Sociological Review, 3(5), 672-682.

Mirels, H. L., \& Garrett, J. B. (1971). Protestant ethic as a personality variable. Journal of Consulting and Clinical Psychology, 36, 40-44.

Olason, D. T., Hayer, T., Brosowski, T., \& Meyer, G. (2015). Gambling in the mist of economic crisis: Results from three national prevalence studies from Iceland. Journal of Gambling Studies, 31(3), 759-774.

Papke, L. E., \& Wooldridge, J. M. (1996). Econometric methods for fractional response variables with an application to 401(k) plan participation rates. Journal of Applied Econometrics, 11(6), 619-632. https://doi.org/10.2307/2285155.

Pravichai, S., \& Ariyabuddhiphongs, V. (2014). Superstitious beliefs and problem gambling among Thai lottery gamblers: The mediation effects of number search and gambling intensity. Journal of Gambling Studies, 31(4), 1633-1649. https://doi.org/10.1007/s10899-014-9517-7.

Richter, D., \& Schupp, J. (2012). SOEP innovation sample (SOEP-IS)_Description, structure and documentation. SOEPpaper 463. Berlin: DIW Berlin.

Rogers, P. (1998). The cognitive psychology of lottery gambling. A theoretical review. Journal of Gambling Studies, 14(2), 111-134.

Rogers, P., \& Webley, P. (2001). "It could be us!": Cognitive and social psychological factors in UK national lottery play. Applied Psychology, 50(1), 181-199. 
Rosecrance, J. (1986). Why regular gamblers don't quit: A sociological perspective. Sociological Perspectives, 29(3), 357-378.

Sarti, S., \& Triventi, M. (2017). The role of social and cognitive factors in individual gambling: An empirical study on college students. Social Science Research, 62, 219-237. https://doi.org/10.1016/j. ssresearch.2016.08.009.

Smith, A. (1904 [1776]). An inquiry into the nature and causes of the wealth of nations. London: Methuen \& Co., Ltd. Retrieved February 9, 2017 from the World Wide Web: http://www.econlib.org/library/ Smith/smWN.html.

SOEP IS. (2014). SOEP-IS Release 2014, data 1998-2014. https://doi.org/10.5684/soep.is.2014.1.

Welte, J. W., Barnes, G. M., Tidwell, M.-C. O., \& Wieczorek, W. F. (2017). Predictors of problem gambling in the US. Journal of Gambling Studies, 33(2), 327-342. 